\title{
PREVALENSI PENYAKIT KECACINGAN DAN HUBUNGANNYA DENGAN ANEMIA PADA ANAK SEKOLAH DASAR YANG ADA DI KOTA MAKASSAR
}

\author{
Prawansa Amran \\ Jurusan Analis Kesehatan Poltekkes Kemenkes Makassar
}

Koresponden: amranprawansa67@gmail.com

\begin{abstract}
ABSTRAK
Penyakit kecacingan termasuk salah satu faktor yang dapat mempengaruhi kualitas sumber daya manusia karena penyakit tersebut akan mempengaruhi gizi, daya kognitif dan produktifitas kerja. Dalam rangka Indonesia sehat 2020, pembangunan kesehatan merupakan bagian yang tidak terpisahkan dari pembangunan nasional, yang bertujuan untuk mewujudkan manusia yang sehat, produktif dan mempunyai daya saing yang tinggi. Salah satu ciri bangsa yang maju adalah bangsa yang mempunyai derajat kesehatan yang tinggi dengan mutu kehidupan yang tinggi pula. Di Indonesia masih banyak penyakit yang merupakan masalah kesehatan, salah satu diantaranya adalah penyakit anemia dan kecacingan. Penelitian yang dilakukan bertujuan untuk mengetahui Prevalensi penyakit kecacingan dan kejadian Anemia pada anak sekolah dasar serta menghubungkan penyakit kecacingan dengan kejadian anemia. Penelitian yang dilakukan merupakan observasi laboratorik yakni melakukan uji laboratorium untuk mengetahui prevalensi penyakit kecacingan dan kejadian Anemia serta hubungannya dengan Anemia pada anak Sekolah Dasar yang ada di Kota Makassar. Berdasarkan tujuan penelitian untuk mengatahui prevalensi Penyakit kecacingan ditemukan Anak Sekolah yang ada di Kota Makassar mengalami penyakit kecacingan adalah 18 siswa atau $18 \%$, Laki-Laki $8 \%$ dan perempuan 105, sedangkan Prevalensi kejadian Anemia pada Anak Sekolah Dasar adalah 35 siswa atau $35 \%$, Laki-Laki $19 \%$ dan perempuan $16 \%$ data tersebut diperoleh dari 100 siswa yang dijadikan sampling yang diambil dari 3 (tiga) lokasi Sekolah Dasar yang ada di Kota Makassar. Semua Anemia yang ditemukan pada anak sekolah dasar masih kategori anemia ringan. Penelitian ini menunjukkan adanya peningkatan kasus kecacingan dan kejadian anemia di Makassar masih meningkat berdasarkan laporan dari Riskesda yang melaporkan bahwa kejadian anemia tahun 2013 sebesar 26,4 \%. Kejadian Penyakit Kecacingan dengan Kejadian Anemia dalam penelitian ini ditemukan ada hubungan antara Penyakit Kecacingan dengan Kejadian Anemia.
\end{abstract}

Kata Kunci: Prevalensi Kecacingan, Anemia

\section{PENDAHULUAN}

Pembangunan disektor kesehatan bertujuan untuk meningkatkan kualitas sumber daya manusia. Penyakit kecacingan termasuk salah satu faktor yang dapat mempengaruhi kualitas sumber daya manusia karena penyakit tersebut akan mempengaruhi gizi, daya kognitif dan produktifitas kerja. Dalam rangka Indonesia sehat 2020, pembangunan kesehatan merupakan bagian yang tidak terpisahkan dari 
pembangunan Nasional, yang bertujuan untuk mewujudkan manusia yang sehat, produktif dan mempunyai daya saing yang tinggi. Salah satu ciri bangsa yang maju adalah bangsa yang mempunyai derajat kesehatan yang tinggi dengan mutu kehidupan yang tinggi pula.

Di Indonesia masih banyak penyakit yang merupakan masalah kesehatan, salah satu diantaranya adalah Anemia, Kecacingan yang disebabkan oleh Cacing Nematoda usus khususnya pada anak-anak yang ditularkan melalui tanah (Soil Transmitted Helminth). Kecacingan ini dapat mengakibatkan penurunan kondisi kesehatan, gizi, kecerdasan dan produktifitas penderitanya karena dapat menyebabkan kekuranan karbohidrat dan protein serta kehilangan darah, sehingga dapat disimpulkan bahwa hal tersebut dapat menurunkan kualitas sumber daya manusia.(cermin dunia kedokteran no.124,1999)

Anemia Merupakan salah satu masalah kesehatan di seluruh Dunia terutama negara berkembang yang diperkirakan $30 \%$ penduduk dunia menderita anemia. Anemia banyak terjadi pada masyarakat terutama pada anak, remaja dan ibu hamil. Menurut World Health Organization (WHO) tentang prevalensi anemia dunia berkisar 40-88\%. Menurut Laporan Kemennterian Kesehatan RI 2013 Jumlah penduduk usia anak-anak sampai remaja $(7-19$ tahun $)$ di Indonesia sebesar $26,2 \%$ yang terdiri dari $50,9 \% \quad$ laki-laki dan $49,1 \%$ Perempuan. Menurut Data Riskesdas 2013 prevalensi anemia di Indonesia yaitu $21,7 \%$, dengan proporsi $20,6 \%$ di perkotaan dan $22,8 \%$ di pedesaan serta $18,4 \%$ laki-laki dan $23,9 \%$ perempuan. Berdasarkan kelompok umur penderita anemia berumur $5-14$ tahun sebesar 26,4\%, dan sebesar $18,4 \%$ pada kelompok umur 15-24 tahun.

Faktor yang mempengaruhi tingginya prevalensi kecacingan juga mempengaruhi tingginya penyakit Anemia karena Indonesia terletak di daerah tropik dimana hal ini merupakan tempat yang ideal bagi perkembangan telur cacing. Kurangnya pengetahuan mengenai hygiene perorangan dan sanitasi lingkungan serta sosial ekonomi (Rampengan TH,1997).

Salah satu upaya pemerintah Indonesia dalam menanggulangi penyakit dengan cara diadakan program pembangunan kesehatan yang diarahkan untuk meningkatkan kualitas sumber daya manusia (SDM) serta kualitas kehidupan, terpadu dan berkesinambungan, serta perbaikan status gizi.

Namun kenyataan usaha tersebut belum memperlihatkan hasil yang maksimal, hal ini di karenakan masih ditemukan beberapa permasalahan akan kesehatan masyarakat. Salah satunya penyakit yang disebabkan parasit yaitu kecacingan. Ini terlihat masih tingginya prevalensi kecacingan yang terjadi di Indonesia.

Anak sebagai generasi penerus adalah pewaris cita-cita perjuangan bangsa yang merupakan sumber daya manusia yang sangat penting dalam mencapai keberhasilan pembangunan. Untuk menjadi sumber daya manusia yang berkualitas maka pembinaan sejak dini terhadap anak sangat penting, dan untuk mewujudkan semua ini, anak harus dituntut selalu sehat secara jasmani dan rohani.

Dalam kesadaran tinggi dan keadaan perekonomian yang stabil, 
Tentu tidak ada orang tua yang rela membiarkan anak-anaknya untuk terkena penyakit khususnya Kecacingan yang dapat mempengaruhi menderita Anemia sehingga dapat menurungkan kecerdasan anak. Anak biasanya tidak mengetahui pentingnya kesehatan sehingga anak-anak tidak menyadari bahwa tempat biasanya bermain banyak sekali terdapat bibit penyakit yang sewaktu-sewaktu menyerang dirinya dan segala aktivitas dengan tidak memperdulikan keadaan disekitarnya. Kehidupan yang bebas yang dijalani oleh anak-anak tidak dapat mengontrol dirinya,

Kecacingan sangat mempengaruhi terjadinya Anemia. Anemia adalah kumpulan gejala yang ditandai dengan kulit dan membran mukosa pucat, dan pada test laboratorium didapatkan kadar hemoglobin, hematokrit $(\mathrm{Hm})$, dan eritrosit kurang dari normal. Insidennya $30 \%$ pada setiap individu diseluruh dunia, prevalensinya terutama tinggi di negara berkembang karena faktor defisiensi diet atau kehilangan darah akibat infeksi parasit (Hardjoeno.H, 2006).

Anemia merupakan keadaan menurunnya kadar hemoglobin, hematokrit dan jumlah sel darah merah di bawah nilai normal yang dipatok untuk perorangan (Arisman, 2008). Anemia sebagai keadaan dimana level hemoglobin rendah karena kondisi patologis. Defisiensi $\mathrm{Fe}$ merupakan salah satu penyebab anemia, tetapi bukanlah satu-satunya penyebab anemia (Fatmah dalam FKM UI, 2007). Berdasarkan uraian di atas maka penulis ingin melakukan penelitian untuk mengetahui prevalensisi penyakit kecacingan, Anemia dan pada anakanak sekolah Dasar di beberapa
Sekolah Dasar yang ada di Kota Makassar. Tujuan penelitian adalah untuk mengetahui Prevalensi kejadian penyakit kecacingan Pada anak Sekolah Dasar yang ad di Kota Makassar, untuk mengetahui Prevalensi Kejadian Anemia Pada Anak Sekolah Dasar yang ada di Kota Makassar, untuk mengetahui apakah ada hubungan Angka Kejadian Kecacingan dengan Angka Kejadian Anemia.

\section{METODE}

\section{Jenis penelitian, waktu, dan tempat penelitian}

Jenis Penelitian ini merupakan survey untuk mengetahui prevalensi penyakit kecacingan dan anemia dengan melakukan pemeriksaan feces dan Kadar hemoglobin secara Laboratorium. Penelitian dilaksanakan di Laboratorium Jurusan Anaalis Kesehataan Poltekkes Kemenkes Makassar bulan Juli 2017

\section{Populasi dan Sampel}

Populasi dalam penelitian ini adalah Sekolah Dasar yang ada di Kota Makassar. Sampel yang digunakan dalam penelitian ini adalah Anak Sekolah dasar yang diambil darahnya dan Fecesnya yang dijadikan sebagai sampling penelitian sebanyak 100 siswa

\section{Teknik Pengumpulan Data}

a. Pemeriksaan Feces

Alat dan bahan yang digunakan dalam penelitian ini adalah : Objeck glass, Mikroskop, Lidi, Zat Warna. Prosedur kerja : Pertamapertama feces diambil dengan menggunakan lidi yang telah disiapkan dan diletakkan diatas objeck glass yang terlebih dahulu ditetesi zat warna Eosin $2 \%$, selanjutnya dapat diperiksa secara 
mikroskopis dengan pemebesaran objektif $10 \mathrm{X}$ dan $40 \mathrm{X}$.

Interpretasi Hasil : Positif (+) Jika ditemukan telur cacing dalam lapang pandang lebih dari satu

Dan Negatif (-) jika tidak ditemukan telur cacing dalam lapang pandang.

b. Pemeriksaan Kadar haemoglobin

Disiapkan semua alat yang digunakan, kemudian alat Essy Touch di Tes terlebih dahulu apakah alat tersebut siap untuk digunakan, Strep di masukkan kedalam alat, dan alat akan memperlihatkan gambar tetesan darah (alat siap dugunakan), darah diambil dibagian kapiler, kemudian darah yang dikeluarkan diisap dengan menggunakan strip yang sudah menempel pada alat Essy Touch, selanjutnya waktu berjalan dan dapat dilihat pada alat, dan beberapa detik akan memperlihatkan hasil kadar Hemoglobin pada monitor pada alat Interpretasi Hasil :

Nilai Normal Hemoglobin adalah :

Perempuan : $12-16 \mathrm{~g} \%$

Laki Laki : $14-18 \mathrm{~g} \%$

Anak-Anak : :11,5-16 g\%

Bayi Baru Lahir : $12-14 \mathrm{~g} \%$
Analisis Data

Analisis data dilakukan secara deskriptif yang disajikan dalam bentuk prosentase dan memnghubungkan Kecadian kecacingan denga kejadian anemia den dinarasikan.

Rumus :

1. Persentasi Kejadian kecacingan dan Anemia.

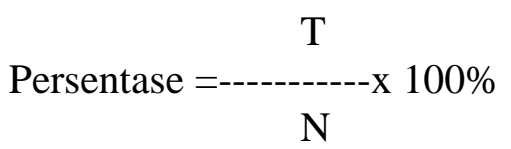

Keterangan :

$\mathrm{T}$ adalah Jumlah saampel positif

$\mathrm{N}$ adalah banyaknya sampel

2. Analisis Hubungan Kecacingan dengan kejadian Anemia dengan menggunakan Uji Chi-Square Test

\section{HASIL}

Berdasarkan hasil penelitian yang telah dilakukan dan diperoleh data hasil pemeriksaan feces, dan Hasil Pemeriksaan Haemoglobin ( $\mathrm{Hb}$ ), data ini diperoleh dari 3 (tiga) Lokasi SD yang diambil sebagai populasi dan dijadikan sebagai sampling Penelitian sebanyak 100 siswa, dan dapat dilihat berikut ini.

Tabel 1.

Hasil Pemeriksaan Feces dan Pemeriksaan Haemoglobin

\begin{tabular}{cccc}
\hline Lokasi & $\begin{array}{c}\text { Jumlah } \\
\text { Siswa }\end{array}$ & $\begin{array}{c}\text { Siswa } \\
\text { Anemia }\end{array}$ & $\begin{array}{c}\text { Siswa (+) } \\
\text { Kecacingan }\end{array}$ \\
\hline SD.1 & 49 & 18 & 12 \\
SD.2 & 29 & 8 & 2 \\
SD.3 & 22 & 9 & 4 \\
Total & 100 & 35 & 18 \\
\hline
\end{tabular}

Berdasarkan data dari Tabel 1. ditemukan jumlah siswa yang mengalami anemia 35 siswa dan siswa yang mengalami kecacingan sebanyak
18 siswa, data ini diambil dari 3 (tiga) lokasi Sekolah Dasar dengan jumlah siswa sebanyak 100 siswa. 
Tabel 2.

Prevalensi Kejadian Kecacingan dan Anemia pada Anak Sekolah Dasar yang ada di Kota Makassar

\begin{tabular}{cccc}
\hline \multirow{2}{*}{ Kejadian } & \multirow{2}{*}{ Prevalensi } & \multicolumn{2}{c}{ Jenis Kelamin } \\
\cline { 3 - 4 } & & Laki-Laki & Perempuan \\
\hline Kecacingan & $18 \%$ & $8 \%$ & $10 \%$ \\
Anemia & $35 \%$ & $19 \%$ & $16 \%$ \\
\hline
\end{tabular}

Prevalensi kejadian Kecacingan ditemukan Kecacingan 18 siswa (18 dan Kejadian Anemia yang ada \%), laki-laki $8 \%$, perempuan 10 siswa dikalangan Sekolah Dasar dari 3 (tiga) (10\%). Prevalensi Kejadian anemia 35 lokasi yang dijadikan sampling Siswa, Laki-laki $19 \%$, perempuan 16 penelitian berjumlah 100 siswa $\%$.

Tabel 3.

Tabulasi Hubungan Kecacingan dengan Anemia

\begin{tabular}{ccccc}
\hline Jenis & \multicolumn{3}{c}{ Anemia } & \multirow{2}{*}{ Total } \\
\cline { 2 - 4 } Kasus & & Tidak & Ya & \\
\hline \multirow{2}{*}{ Kecacingan } & Tidak & 59 & 21 & 80 \\
Total & Ya & 9 & 11 & 20 \\
& & 68 & 32 & 100
\end{tabular}

kecacingan adalah 80 siswa, siswa

Dari tablel 3. menunjukkan bahwa jumlah siswa yang tidak terinfeksi cacing sebanyak 59 siswa, tetapi 21 siswa yang anemia, sehingga total siswa yang tidak mengalami yang terinfeksi cacing sebanyak 11 siswa tetapi tidak mengalami anemia sebanyak 9 siswa sehingga totalnya 20 siswa yang mengalami kecacingan. Total siswa keseluruhan 100 siswa.

Tabel 4.

Test Statistik : Uji Chi-Square

\begin{tabular}{cc}
\hline & $\begin{array}{c}\text { Pengaruh Kecacingan } \\
\text { terhadap Anemia }\end{array}$ \\
\hline $\begin{array}{c}\text { Chi- } \\
\text { Square }\end{array}$ & .014 \\
\hline $\mathrm{df}$ & 1 \\
\hline Sig (2-) & .030 \\
\hline
\end{tabular}


Jurnal Media Analis Kesehatan, Vol. 8, No.2, November 2017

http://journal.poltekkes-mks.ac.id/ojs2/index.php/mediaanalis

e-ISSN : 2621-9557

p-ISSN : 2087-1333

Dari tabel di atas diperoleh nilai p-value $=$ .030, Karena p-value $<\alpha(0.03<0.05)$ maka Ho ditolak Jadi dapat disimpulkan bahwa ada hubungan kecacingan dengan penyakit anemia.

\section{PEMBAHASAN}

Kejadian Kecacingan masih banyak ditemukan dikalangan anak-anak khususnya yang masih duduk dibangku Sekolah Dasar masih rawang terinfeksi cacingan, kita ketahui bahwa infeksi cacing pada anak-anak sangat berbahaya bagi pertumbuhan anak itu sendiri. Cacing yang banyak menginfeksi manusia adalah golongan cacing Nematoda Usus seperti Cacing Ascaris lumbricoides (cacing Gelang), Cacing Tambang (Ancylostoma), Cacing Cambuk (Trichuris trichiura), Cacing Kremi (Oxiuris vermicularis).

Cacing tersebut ditas memiliki habitat yang berbeda, untuk Ascaris lumbricoides hidup dalam usus halus, sehingga dapat merugikan karena mengambil sari-sari makanan dalam usus, sehingga dapat menyebabkan kekurangan gizi sehingga akan berpengaruh pada kualitas hidup seseorang dan mengganggu produktifitas kerja. Pada kondisi anak-anak yang terinfeksi cacing tersebut akan menyebabkan terganggunya prestasi belajar karena pada keadaan kurang gizi maka dapat menyebabkan lesu pada anak, sehingga dapat mempengaruhi konsentrasi belajar disekolah. Berdasarkan sifat daric acing tersebut khususnya berdasarkan cara siklus hidup cacing di dalam tubuh manusia adalah Cacing dewasa dalam usus akan menghasilkan telur fertile dan dapat ditemukan dalam tinja penderita, selanjutnya tinja kontak dengan tanah dan akan terbawah oleh debu, kotoran masuk ke dalam tubuh melalui mulut bersama dengan makanan dan minuman, selanjutnya telur cacing akan masuk kedalam usus dan menetas menjadi larva. Larva akan akan menginvasi aliran darah dan mengalir bersama darah sampai ke paru-paru sehingga dapat menimbulkan refleksi batuk, dan larva akhirnya masuk kembali ke usus dan akan tinggal di usus dan menjadi dewasa dan menghasilkan kurang lebih 200,000 telur per harinya dan menghisap darah 0,5 sampai $1 \mathrm{ml}$ per harinya untuk setiap ekor cacing dewasa.

Pada kasus kecacingan yang ditemukan pada penelitian ini dengan mengambilan sampling dari 3 (tiga) lokasi Sekolah Dasar yang ada di Kota Makassar ditemukan jumlah anak yang mengalami kecacingan berjumlah 18 siswa atau $18 \%$, laki-laki $8 \%$ dan perempuan $10 \%$ dari 100 jumlah siswa yang berumur $7-11$ tahun yang di jadikan sampling penelitian, walaupun pemerintah telah melakukan program pemberian obat cacing yang diberikan pada anak Sekolah Dasar yang ada di Kota Makassar, tetapi masih di temukan Anak Sekolah Dasar yang kecacingan, ini berarti masih ada anak atau orang tua yang belum memahami pentingnya pencegahan dan pengobatan penyakit kecacingan, sehingga yang perlu diperhatikan oleh pemerinta tidak hanya memberikan obat tetapi perlu adanya penyuluhan untuk memberikan pemahaman pentingnya pencegahan dan pengobatan penyakit kecacingan dikalangan anak Sekolah Dasar. Sedangkan pada angka kejadian anemia dikalangan Anak Sekolah Dasar berdasarkan penelitian yang dilakukan juga mengambil 3 (tiga) lokasi Sekolah Dasar yang ada di Kota Makassar bahwa kejadian anemia yang ditemukan dikalangan Anak Sekolah Dasar yang ada di Kota Makassar sebanyak 35 siswa, laki-laki $19 \%$ dan perempuan $16 \%$ dari 100 siswa yang 
Jurnal Media Analis Kesehatan, Vol. 8, No.2, November 2017

http://journal.poltekkes-mks.ac.id/ojs2/index.php/mediaanalis

e-ISSN : 2621-9557

p-ISSN : 2087-1333

berumur 7 - 11 tahun di jadikan sebagai sampling penelitian sehingga prevalensi kejadian anemia di kalangan Anak Sekolah Dasar adalah $35 \%$. Ini berarti masih ada peningkatan berdasarkan laporan Riskesdas 2013 yang melaporkan kejadian anemia sebesar $26.4 \%$.

Berdasarkan uji statistik dengan menguji secara Chi-Square Test untuk mengetahu apakah ada hubungan antara Penyakit kecacingan dengan anemia dari data diperoleh table Uji Chi-Square antara kecacingan dengan penyakit anemia dinyatakan ada hubungan kecacingan dengan penyakit anemia. Walaupun sebelum penelitian dilakukan pengobatan melalui pemberian obat cacing pada anakanak melalui Sekolah Dasar yang ada di Kota Makassar.

Jadi Anemia terjadi karena kurangnya asupan zat besi dalam makanan menjadi penyebab anemia nomor satu di Indonesia. Penderita anemia perlu meningkatkan jumlah konsumsi makanan yang kaya akan zat besi dan membuat menu makanan yang memenuhi konsep pedoman gizi seimbang, makanan seperti bayam, tahu, brokoli, ikan dan daging merah memiliki kandungan zat besi yang tinggi. Malabsorpsi adalah kondisi ketika tubuh tidak bias menyerap nutrisi termasuk zat besi dari makanan yang dicerna tubuh. Kondisi malabsorpsi juga bias menyebabkan anemia defisiensi besi. Malabsorpsi contohnya bias terjadi dalam kondisi berikut ini :

1. Penderita penyakit Cellac atau Intoleransi terhadap gluten

2. Intoleransi usus terhadap bahan makanan tertentu seperti laktosa dalam susu

3. Penderita Penyakit Crohn

4. Penderita colitis Ulseratif
5. Pascaoperasi pengangkatan bagian lambung yang dikenal sebagai gastrektomi

6. Infeksi cacing tambang atau Nemastoda usus adalah Parasit yang hidup dalam usus halus manusia. Banyak orang yang terinfeksi cacing tambang dan tidak menyadarinya, karena kondisi ini tidak memiliki gejala yang signifikan . Cacing tambang menyerap makanan dan darah

\section{KESIMPULAN}

Berdasarkan hasil penelitian yang dilakukan untuk mengetahui Prevalensi penyakit Kecacingan dan prevalensi Kejadian Anemia pada anak Sekolah Dasar dengan jumlah sampel 100 Siswa dari 3 (tiga) Sekolah Dasar yang ada di Kota Makassar maka dapat disimpulkan :

1. Prevalensi Penyakit Kecacingan pada anak SD sebanyak $18 \%$ yang terdiri dari Laki-Laki $8 \%$ dan perempuan 10 $\%$, umur $7-11$ tahun

2. Prevalensi Kejadian Anemia pada Anak SD sebanyak $35 \%$ yang terdiri dari Laki-Laki $19 \%$ dan Perempuan $16 \%$, umur 7 - 11

3. Berdasarkan Uji Chi - squaret ditemukan ada hubungan penyakit kecacingan dengan kejadian Anemia.

\section{DAFTAR PUSTAKA}

Depkes, 2015 Pedoman Pengendalian Kecacngan. Diakses pada tanggal 26 Juni 2015

Entjang I 2003. Mikrobiologi dan Parasitologi Untuk Akademi keperawatan, PT Citra Aditya Bakti, Bandung.

Gandahusada S, Ilahude H D,Pribadi W, 2000. Parasitologi Kedokteran, Jakarta, Fakultas Kedokteran Universitas Indonesia, Edisi III. 
Jurnal Media Analis Kesehatan, Vol. 8, No.2, November 2017

http://journal.poltekkes-mks.ac.id/ojs2/index.php/mediaanalis

e-ISSN : 2621-9557

p-ISSN : 2087-1333

Garcia LS, 1996. Diagnosis Parasitologi Kedokteran, Penerbit Buku kedokteran EGC, Jakarta.

Http ; id wikipedie / wik i/ cacing kremi.6,2013.

Inge S,Is Suharsiah I,Pudji K S, Sungkar Saleha,2009. Parasitologi

Kedokteran, Jakarta, fakultas Kedokteran Universitas Indonesia, Edisi IV.

Naim 2009,Identifikasi telur nematoda usus pada anak balita penghuni tempat penitipan anak masagena Kota Makassar Prodi Analis Kesehatan Politehnik Kesehatan Makassa.

Natadistra Djainuddin,Agus Ridad,2009. Parasitologi Kedokteran. penerbit buku kedokteran EGC,Jakarta.
Onggowaluyo JS, 2001. Parasitologi Medik I Helmintologi, EGC, Jakarta.

Prianto,J,Tjahayu,Darwanto,1994.Atlas Parasitologi Kedokteran, ECG Jakarta.

Politeknik kesehatan kementerian kesehatan Makassar.2013. Penuntun Praktikum Parasitologi 1. Analis kesehatan Makassar.

Rampengan, 1995. Penuntun Praktikum Parasitologi Medik, Bhakti Wijaya Kediri, AAK Depkes Surabaya.

Ompusunggu sahat, 1999.Cermin Dunia Kedokteran,Jakarta.

Soedarto, 1995. Helmintologi Kedokteran, EGC, Jakarta

Soedarto, 2008.Parasitologi Klinik, Airlangga university, Surabaya 